\title{
Interactive Multimedia Language Skills For Primary School Teacher Education Study Program
}

\author{
Biya Ebi Praheto ${ }^{1}$, Andayani $^{2}$, Muhammad Rohmadi $^{3}$, Nugraheni Eko Wardani ${ }^{4}$ \\ 1 biya.ebi@ustjogja.ac.id, ${ }^{2}$ bu_anda09@yahoo.co.id, ${ }^{3}$ rohmadi_dbe@yahoo.com, \\ ${ }^{4}$ Nugraheniekowardani_99@yahoo.co.id \\ ${ }^{1,2,3,4}$ Sebelas Maret University, Surakarta, Indonesia
}

\begin{abstract}
Learning skills Indonesian language has an essential role for prospective primary school teachers in the primary school teacher education study program. Learning Indonesian skills will equip students with four aspects of the profession such as listening, speaking, reading, and writing skills. Based on the results of preliminary observations, indicate that student difficulty in the learning and the needs of students on interactive multimedia. Based on the considerations which are developed interactive multimedia for learning Indonesian language skills that include several menus such as home, semester learning plan, materials, games, music, profiles, and references. In addition, there are evaluations, examples, animations, videos, and images in interactive multimedia.
\end{abstract}

Keywords: Interactive Multimedia, language skills, Primary School Teacher Education.

\section{Introduction}

Language has an important role in education. It cause of all activities in education has been ensured to use the language as the communication language, especially in the implementation of learning. Similarly, the role of Indonesian language for primary school teachers. Therefore, Indonesian language skills courses become one of the compulsory subjects that must be taken by students in the primary school teacher education study program. Indonesian language skills include four aspects of listening, speaking, reading and writing skills. Based on observations in various education programs of primary school teachers in some universities shows that $63.45 \%$ of students stated that Indonesian language skills courses are difficult courses. One of the causes is the lack of adequate learning media in the implementation of learning Indonesian language skills. Lecturers only use PowerPoint as media and more text-based, so less interactive and interesting.

Media has an important role in learning as an intermediary learning materials between teachers and learners, so the learning material can be delivered properly [1]. In addition, the benefits of learning media in purpose to standarize when delivery a learning materials and make interesting and attractive learning. The amount of teaching and learning time can be reduced, the increase of student learning quality and positive attitude of students to the learning process, happens anywhere and at any time, and the teacher's role can change to a more positive and productive direction[2].

Seeing the importance of learning media, then one of the solutions in learning Indonesian language skills in the Primary School Teacher Education Study Program is to develop or design an interesting and interactive learning media for students. The media is an interactive multimedia based Adobe Flash. Multimedia is a combination of various media (file format) in the form of text, images, graphics, sound, animation, video, interaction, and others that have 
been packaged into digital files (computerized), used to convey or deliver messages to the public[3]. Learning Indonesian skills that not only requires students to understand the material cognitively but also required to be skilled in Indonesian language, the interactive multimedia has an important role in learning. Furthermore, the effectiveness and benefits of multimedia, making interactive multimedia helps students in mastering the material as well as motivating students to learn. Therefore, with interactive multimedia, messages in the form of learning materials easier to be submitted and accepted by students. As a result, interactive multimedia can improve the quality of process and results in learning Indonesian language skills[4]. Multimedia can gives an effective education and facilitate the education. Multimedia provides facilities in education. Because of multimedia practice, students can learn new information[5].

Interactive multimedia is already very popular in education. Various interactive multimedia is designed to help the learning process. Utilization of technology in teaching should be done following the development of science. Some of the previous studies related to interactive multimedia was conducted by Chachil who developed interactive multimediabased mobile applications for Iban language learning[6]. A similar study was conducted by Salameh by developing an offline multimedia based mobile-phone system for learning English[7]. In addition, Ampa conducted research with the application of interactive multimedia for learning listening skills[8]. Furthermore, Research which is conducted by Majid also develops interactive multimedia in language learning ie English[9]. Then Zainuddin which is doing research related to multimedia which is developing multimedia Courseware for learning Arabic vocabularies[10].

Multimedia in learning is already widely developed, but there has been no interactive multimedia development of Indonesian language skills for the Primary School Teacher Education study program. The design of interactive multimedia skills of Indonesian language is based on the results of observations to lecturers and students. It is expected that interactive multimedia developed in accordance with the needs of students and lecturers in learning Indonesian language skills

\section{Method}

This research is a development research. The first stage is an observation of the needs of students and lecturers in the primary school teacher education study program on interactive multimedia skills in Indonesian language. The observations were conducted in the Primary School Teacher Education Study Program from Universities in Special Region of Yogyakarta and Central Java, such as Sarjanawiyata Tamansiswa University, Ahmad Dahlan University, IKIP PGRI Wates University, Selamet Riyadi University, and Tunas Pembangunan University. Observation is done by interview technique, questionnaire, and document. The observation results are used as a reference for the development of interactive multimedia, in purpose to suit the needs of students and lecturers to learn Indonesian language skills.

\section{Discussion}

Development of interactive multimedia skills of Indonesian language for the Primary School Teacher Education Study Program is agreed to the needs of students and lecturers. Based on the observation, both lecturers and students stated need interactive multimedia for 
learning Indonesian language skills. It can be known that some of the students desire to develop multimedia in learning process: 1) $98.62 \%$ of students want the existence of learning objectives in multimedia; 2) $71.72 \%$ of students want the presentation of the material brief and clear, while the remaining $27.59 \%$ want the presentation of the material described as clear as possible; 3) $99.31 \%$ of students want the existence of examples of application of language in multimedia; 4) $97.24 \%$ of students want a learning evaluation; 5) $82.07 \%$ of students want a brightly colored multimedia display, while the remaining $12.41 \%$ want the display with dark colors;6) $90.34 \%$ of students want a back sound or sound effects in multimedia; 7) $96.55 \%$ of students want a picture or animation and 8) $100 \%$ of students want the menu button in interactive multimedia.

Based on the observations, interactive multimedia is developed using adobe flash program. Some of the main menu that is displayed include: 1) Home menu is a welcoming screen of interactive multimedia. When the user pressing home menu then the display will return to the welcoming screen. 2) SLP (Semester Learning Plan) menu is a menu which contains a semester learning plan that contains the existing a material plan in interactive multimedia as well as material plan that will be taught to students for one semester. 3) Material menu is a menu that contains learning material, consisting of five chapters: the nature of language skills, listening skills, speaking skills, reading skills, and writing skills. In each chapter of the material there is a sub-section of the material up to evaluation in practice. 4) Game menu is a menu that consists as an entertainment material in interactive multimedia, so does not cause the student bored. Game contains a game of numbers that formed likely a puzzle which has to solve the numbers to play it. 5) Music menu is a menu that contains several choices of music that users can choose to accompany interactive multimedia when using it. 6) Profile menu is a menu that contains biodata designer and maker of interactive multimedia skills of Indonesian language. 7) Reference menu is a menu that contains a list of library books used to compile the material in the interactive multimedia skills of Indonesian language. 8) $\mathrm{x}$ button is the menu used to close the application when the user has finished using interactive multimedia.

The interactive multimedia display of Indonesian language skills for the primary school teacher education study program is described as follows.



Fig. 1. Display of Login Screen

Figure 1 will appear when opening an interactive multimedia application of Indonesian language skills. Users will be prompted to enter a name before entering further access any available menu. When you typed a name then choose the login button. 


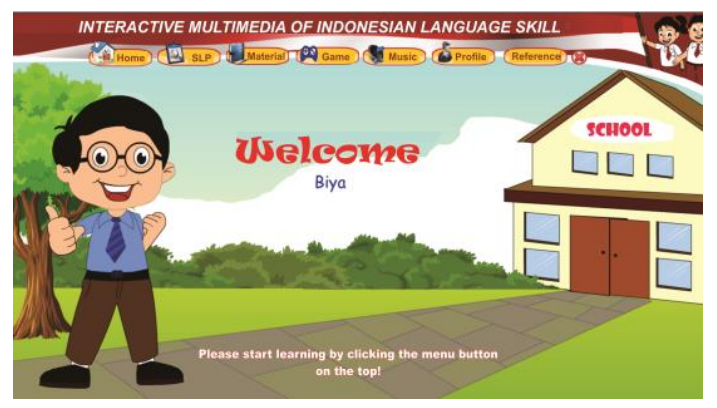

Fig. 2. Display of Welcoming Screen

Figure 2 shows the welcoming screen when the user logs in by typing the name under the space provided in Figure 1. At the top of the welcoming screen there are seven menus and one close (x) button that the user can select. The menu includes home, SLP, Materials, Games, Music, Profiles, and Referrals. Users can select the menu randomly according to the user needs. When the home menu is selected then the display will return on the welcoming screen.

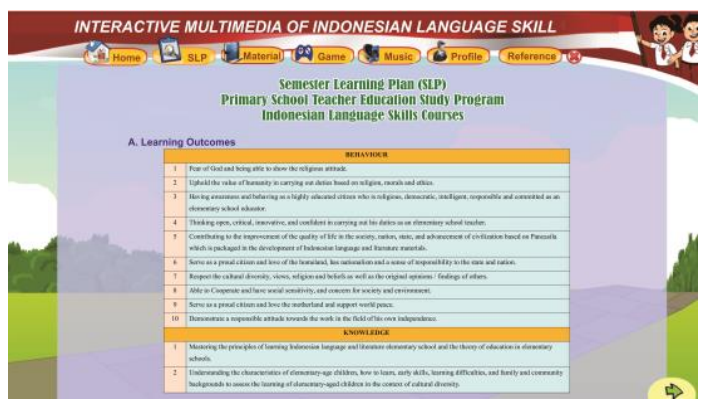

Fig. 3. Display of Semester Learning Plan (SLP) Menu

In the SLP menu picture 3, the user can see the objectives and achievements of learning and distribution of materials that appear in learning Indonesian skills.

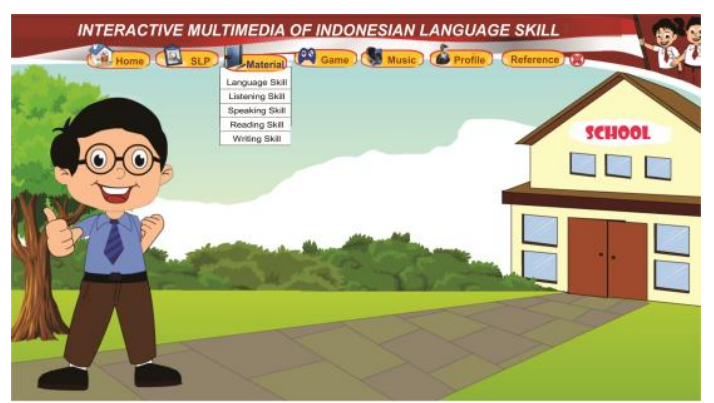

Fig. 4. Display of Material Menu

In the material menu shown in Figure 4, will appear five sub-subject matter of language skills, listening skills, speaking skills, reading skills, and writing skills. Users can choose learning materials according to user needs. 


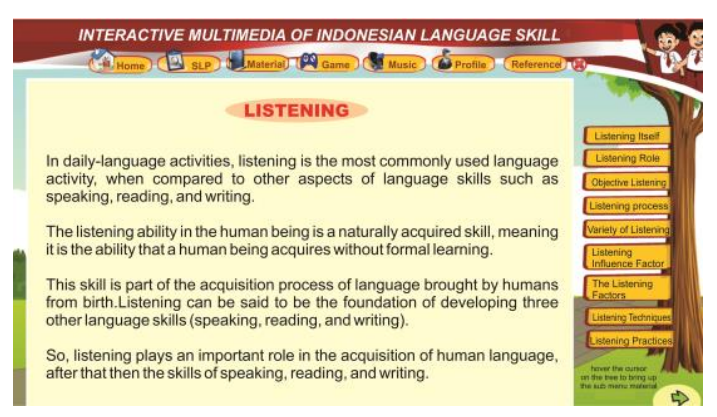

Fig. 5. Display of Content Menu

If in picture 4 user choose one sub main material it will look like in picture 5. To continue to the next page user can click arrow button at bottom right. There is a menu of material in each sub-material that can be viewed when the user hovers over the tree to the right. The menu on the tree can be selected in accordance with the material that users want to learn. Each submaterial will display examples of language usage as well as practice as a learning evaluation. Examples can be images or video.

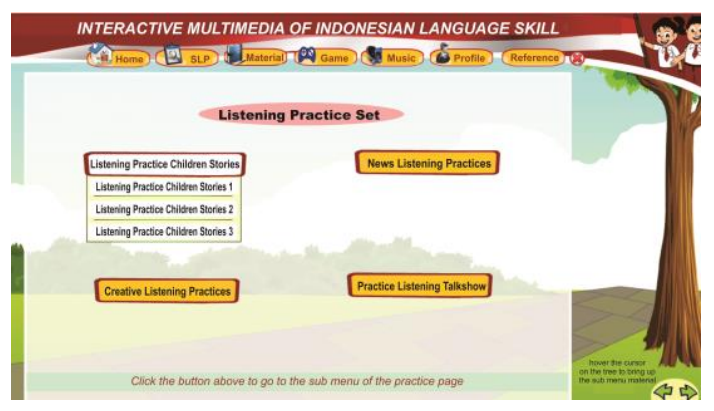

Fig. 6. Display of Practice Sub Menu

In each sub-material that is four language skills there is always a menu of practice as a learning evaluation materials. One of them is shown in Figure 6 which shows the practice of listening skills. There are several practices that students can use to practice.

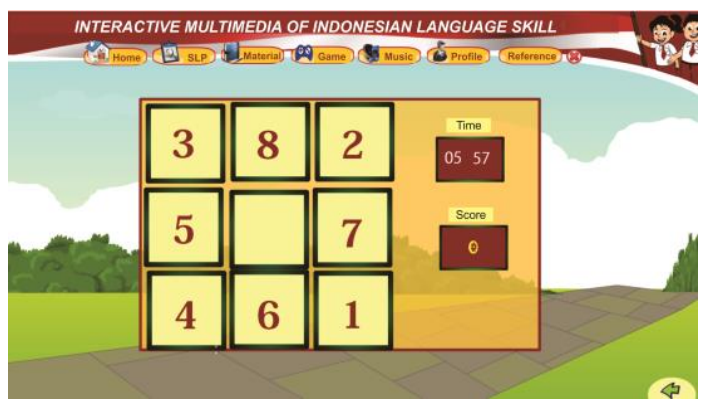

Fig. 7. Display of Game Menu

Figure 7 shows a game menu containing puzzle games composing numbers that can be used as entertainment when the user breaks or feel tired to learn. 




Fig. 8. Display of Music Menu

This interactive multimedia is equipped with a music menu that there are some songs that can be selected as a user partner when using interactive multimedia to learn, especially when studying independently.



Fig. 9. Display of Profile Menu

Profile menu shown in Figure 9. In the menu there are developer biography and interactive multimedia designer of Indonesian language skills for primary school teacher education study program.

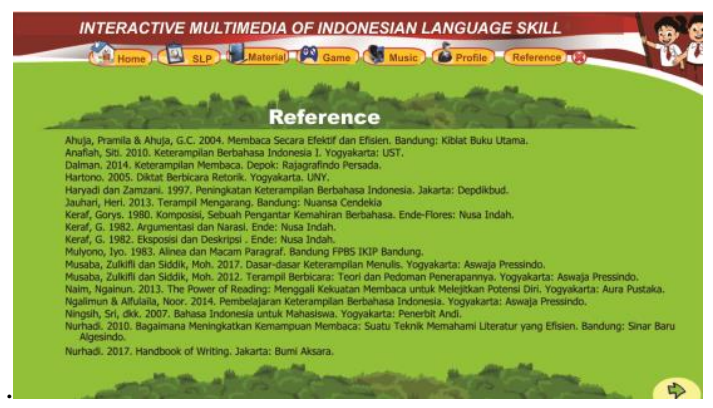

Fig. 10. Display of Reference Menu

On the reference menu, there are several lists of references which is used in the preparation of material Fontaine in the interactive multimedia skills of Indonesian language. If the material contained in multimedia is deemed less by the user, the user can browse the material through the original book contained in the reference list. 
Multimedia interactive of Indonesian skills language developed to help the learning process so that learning achievement can be achieved with the maximum. This interactive multimedia can be used classically by lecturers as a medium of learning in the classroom, or used by students independently to learn. It is expected that with the development of interactive multimedia this learning skills of Indonesian language previously considered difficult will be considered easy for students as well as to increase student motivation.

\section{Conclusion}

Indonesian language skills have an important role in mastering the language skills of the students in the Primary School Teacher Education Study Program. Therefore, it is needed to developed interactive multimedia. Interactive multimedia as a medium that can help the learning process, in purpose and to gain the achievement of learning with the maximum level. The development of interactive multimedia is based on the observation results. Therefore, the development is agreed with the needs of students and lecturers. There is the main menu in interactive multimedia that is the home menu, semester learning plan (SLP), materials, games, music, profiles, and references. In addition, there are evaluations, examples, animations, videos, and images in interactive multimedia.

\section{Acknowledgments}

This research is fully supported by Affiliation Research Grand from Ministry of Research Technology and Higher Education of Republic Indonesia with a contract number: PDD.DIKTI.01/UST/LP3M/K/III/2018.

\section{References}

[1] Hujair AH Sanaky, Media Pembelajaran. Yogyakarta: Safira Insania Press, 2009.

[2] Suwarna, Pengajaran Mikro: Pendekatan Praktis Menyiapkan Pendidik Profesional. Yogyakarta: Tiara Wacana, 2006.

[3] Munir, Multimedia: Konsep \& Aplikasi dalam Pendidikan. Bandung: Alfabeta, 2012.

[4] B. E. Praheto, Andayani, M. Rohmadi, and N. E. Wardani, "Peran Multimedia Interaktif Dalam Pembelajaran Keterampilan Berbahasa Indonesia Di Pgsd," Proceedings, pp. 173-177, 2017.

[5] G. O. Ilhan and Ş. Oruç, "Effect of The Use of Multimedia on Students' Performance : A Case Study of Social Studies Class," Acad. Educ. Res. Rev., vol. 11, no. 8, pp. 877-882, 2016.

[6] K. Chachil, R. M. Rias, A. Engkamat, and A. Sarkawi, "Interactive multimedia-based mobile application for learning iban language," J. Teknol., vol. 75, no. 3, pp. 41-46, 2015.

[7] O. Salomeh, "A multimedia offline cellphone system for English language learning.," Int. Arab J. etechnology pp, vol. 2, no. 1 SRC-GoogleScholar FG-0, pp. 44-48, 2011.

[8] A. T. Ampa, "The Implementation of Interactive Multimedia Learning Materials in Teaching Listening Skills," English Lang. Teach., vol. 8, no. 12, p. 56, 2015.

[9] M. S. Z. B. A. Majid, M. M. B. A. Ali, A. A. B. A. Rahim, and N. Y. B. Khamis, "The Development of Technical English Multimedia Interactive Module to Enhance Student Centered Learning (SCL)," Procedia - Soc. Behav. Sci., vol. 67, no. November 2011, pp. 345$348,2012$.

[10] N. Zainuddin and M. S. Sahrir, "Multimedia Courseware for Teaching Arabic Vocabulary: Let's Learn from the Experts," Univers. J. Educ. Res., vol. 4, no. 5, pp. 1167-1172, 2016. 